\title{
FEATURES OF RESPONSIBILITY FOR DISCLOSURE OF STATE SECRETS IN UKRAINE AND FOREIGN COUNTRIES: COMPARATIVE LEGAL ANALYSIS
}

\author{
L.V. HBUR, PhD (Law), \\ assistant of the department of administrative financial law, \\ National University of Life and Environmental Sciences of Ukraine \\ E-mail: liusiagbur@ukr.net
}

Summary. The article provides a comparative legal analysis of the responsibility for the disclosure of state secrets in Ukraine and foreign countries.

It is taken into account that information that is a state secret is extremely important for society and the state. In addition, they need special and vigilant protection from law enforcement, government agencies and civil society and each individual.

It is emphasized that in modern conditions of global information network development the problems of solving access to information, as well as effective use of state information resources, which also includes information with limited access and the establishment of order to assign information from one category to another, become relevant. The legal institution of state secrets is developed in most countries of the world, where it occupies a special place and is under close attention of the state.

It was found that the legislation of the three studied states (USA, UK, Germany, first of all divides the information into three blocks, and according to the degree of confidentiality of information, measures and the degree of protection of information are determined.

It is concluded that a promising way to protect state secrets and distinguish it from classified information will be to adopt the experience of three separate blocks of information, namely: especially classified information, the disclosure of which provides the highest level of punishment, classified information, responsibility for which should also be expressed and enshrining in the Criminal Code of Ukraine and confidential information, for the disclosure of which to establish administrative liability,

Keywords: information, state secret, secret information, confidentiality, criminal liability

\section{Introduction.}

In modern conditions of global information network development, the problems of solving access to information, as well as the effective use of public information resources, which also includes information with limited access and the establishment of or- der to assign information from one category to another, are gaining relevance.

Information that is a state secret is extremely important for society and the state. In addition, they need special and vigilant protection from law enforcement agencies, government agencies and civil society and each individual. 
It should be noted that the legal institution of state secrets is developed in most countries of the world, where it occupies a special place and is under close attention of the state.

Each criminal offense that is committed is usually enshrined simultaneously in two legal acts, namely in the main legal act governing the object of encroachment and the codified legal act for which criminal liability is provided - the Criminal Code Of Ukraine (hereinafter - the Criminal Code of Ukraine).

Given that Ukraine seeks to be on a par with the world's first powers, there will always be a need to study the functioning of a legal phenomenon through the prism of foreign legislation, including those relating to state secrets, which determines the relevance of this study.

\section{Analysis of recent researches and publications.}

Issues of regulatory and legal support of criminal liability for violation of state secrets in Ukraine and foreign countries in some respects have become the subject of research by such scholars as: M.I. Melnik, T.P. Minka, V.I. Borisov, N.O. Gutorova, V.I. Osadchy, M.I. Panov, M.D. Durmanov, V.P. Yemelyanov, S.M. Alfiorov, M.I. Bazhanov, M.I. Khavroniuk, P.L. Fries, W.D. Menshagin, V.O. Navrotsky, O.M. Djuzha, V.Ya. Tatsiy, S.S. Yatsenko, Yu.V. Baulin, O.O. Dudorov, A.V. Savchenko, M.Y. Korzhansky, P.S. Matyshevsky, V.V. Stashis, E.L. Streltsov and others.

The purpose of thearticle is a comparative analysis of the legal framework for criminal liability for violation of state secrets under the laws of Ukraine and foreign countries.

\section{Results.}

The functioning of the institute of state secrets is regulated by a number of regulations. In addition, the Criminal Code of Ukraine (Criminal Code of Ukraine) provides for certain rules that provide criminal protection of state secrets in Ukraine. At the same time, there is a need for unity and consistency of the conceptual apparatus of this institution, as well as the adequacy of its legal regulation and protection.

Thus, such a situation must comply with the general principles of criminal law - justice and equality (Hbur, 2019: 169).

Recognition of the principle of the rule of law, Ukraine's integration into the world community require new approaches to the formation of legal policy. One of the elements of legal policy that allows for the stable development of social relations is criminal law policy (Kovalyova \& Shpak, 2015).

To begin with, when conducting any research, it is necessary to note what is the subject of such research, namely a state secret.

According to the main sectoral law on state secrets, the Law of Ukraine «On State Secrets» (hereinafter - the Law of Ukraine), state secrets (hereinafter - classified information) - a type of classified information covering information in the field of defense, economics, science and equipment, foreign relations, state security and law enforcement, the disclosure of which may harm the national security of Ukraine and which are recognized in the manner prescribed by this Law, a state secret and subject to state protection.

Thus, it should be noted that based on this definition is the identification of the concept of state secrets and classified information. In Art. 1 of this Law, the terms «state secret» and «secret information» are used in parallel. It can be said that this is 
primarily due to the desire to avoid a tautology in the text of the legislation. However, this use is impractical because the term «classified information» is more general and can be used to describe any public information to which access is restricted.

Yes, in Art. 329 of the Criminal code of Ukraine, the responsibility for loss of the documents containing the state secret is established, loss of documents or other material carriers of the secret information containing the state secret, and also subjects about which information makes the state secret, the person to whom they were entrusted is provided if the loss was the result of a violation of the procedure established by law for the treatment of these documents and other material media of classified information or objects. This example proves that the concept of «classified information» has a broader meaning and covers the concept of «state secret». Although compared to the legislation of other countries, the difference between these two categories is significant.

For comparison, it is sufficient to consider the relevant legislation of several countries - representatives of legal systems belonging to certain families of law. First of all, it is the legislation of Germany (Romano-Germanic legal family), England and the United States (common law family), which differ in their legislation between state secrets and classified information.

The Constitution of Ukraine in Part 1 of Art. 17 declared that the protection of the sovereignty and territorial integrity of Ukraine, ensuring its economic and information security are the most important functions of the state, the business of the entire Ukrainian people. This provision of the Basic Law determines the development and implementation of appropriate means of protection of these values. Of course, all these means must be carried out within the legal field. Given the fact that the XXI century. declared the era of the information society, the protection of information security of any state, including Ukraine, comes to the fore. The most effective tool here is the Criminal Code, the provisions of which are aimed at protecting information, which the state in some way restricts circulation. Information classified as a state secret has the greatest degree of protection.

he National Security Strategy of Ukraine, approved by the Decree of the President of Ukraine dated 26.05.15 № 287 , states that one of the priorities of cybersecurity and security of information resources is to reform the system of protection of state secrets and other information with limited access, protection of state information resources, e-government systems, technical and cryptographic protection of information, taking into account the practice of NATO and EU member states.

Thus, it should be noted that the protection and non-disclosure of state secrets is supported by a large number of regulations.

If we consider international law, which defines the basic provisions on state secrets and their non-disclosure, it is worth focusing on such points.

In the UK, there is a law on the protection of state secrets, which is called «On State Secrets» (Official Secrets Act). This Act was passed in 1989. However, the history of legislation on the protection of state secrets in the UK has its roots in the distant past. It dates back to 1889 , when a law of the same name was first passed. The system of protection of state secrets is set out in the manual on protection of state secrets (Manual of Protective Security), on the basis of which ministries develop their own guidelines (Leyland, 1996: 188).

Under current UK law, restricted information can have four levels of secrecy: 
«Top Secret»; «Secret» (Secret); «Confidential» (Confidential); «For official use» (Restricted). Information classified as «top secret» includes information the unauthorized disclosure of which could jeopardize the internal stability of the United Kingdom or friendly countries; lead to significant human casualties; could cause significant damage to the effectiveness or security of British or Allied forces or intelligence operations; cause significant damage to relations with friendly governments or cause long-term damage to the economy of the Kingdom (Havronyuk, 2006: 328).

In Germany, restricted information also has similar degrees of secrecy to the United Kingdom: «top secret» (Streng Geheim); «Secret» (Geheim); «Confidential» (VS-Vertraulich). It should be noted that in Germany, state secrets include only information that must be kept secret from foreign states in order to prevent harm to the external security of the Federal Republic. At the same time, information that contains information about the conduct of operational and investigative measures is an official secret and is protected by relevant legislation. Liability for breach of official secrecy is established in Section 28 of the Criminal Code of Germany. Relevant documents containing an official secret are marked «For official use» (VS nur fur den dienstgebrauch) («Executive Order $13526 \ldots \gg)$.

In Germany, the system of protection of state secrets intersects with the general system of protection of important secrets in the field of industry and trade (industrial espionage) and is governed by a number of laws, including: Criminal Code, Anti-Competition Act, Anti-Bribery Ordinance, Federal Law on Data Protection, etc. The German Penal Code, for example, stipulates that state secrets are facts, objects and information available only to a limited number of persons who must be kept secret from foreign states in order to prevent harm to the external security of the Federal Republic.

Improving the protection of state secrets is carried out in three areas:

- creation of self-help organizations in industry and development of their activities;

- improvement of legislation in the field of protection of state secrets and company secrets;

- strengthening counterintelligence bodies and giving them great powers, including in the field of protection of state secrets («Instruction sheet...»).

It is important to improve the protection of secrets during military research in Germany to strengthen the powers of counterintelligence agencies, and in particular those of its units that fight espionage and protect state secrets, including in industry.

In the system of ensuring the protection of state secrets in the fight against «industrial espionage» of foreign countries, an important role is played by associations of industrialists, the so-called «self-help» organizations. Such organizations include, for example, the «Coordination Center for Industrial Security», established in $\mathrm{Co}-$ logne in 1969, which solves the problem of ensuring secrecy in the industry of the state («Executive Order 13526...»).

In accordance with para. 1 paragraph. 95 of the Criminal Code of Germany under the «disclosure of a state secret» means the creation of an unauthorized person access or public announcement of a protected state secret, which threatens to cause serious harm to the external security of the Federal Republic. «Unauthorized» is any person who by nature of service or work does not have the right to possess this information. This person may also be recognized as a foreign citizen if he does not meet the criteria of a special addressee (paragraph 94 of the Criminal Code of Germany), ie does not belong to foreign 
intelligence or a foreign government. It should be noted that the application of this rule is limited to those cases where the perpetrator has no secret connection with a representative of a foreign government or treason, otherwise such an act is classified as espionage (paragraph 94 of the Criminal Code) («Instruction sheet...»).

As for the Ukrainian provision of state secrets, if the documents for official use are processed in automated systems, then certain security requirements must be met. Namely, the automated system must be equipped with a firewall, in case of connection to the Internet, the list of persons who have access to the automated system must be approved. Ensuring the confidentiality of state secrets and official secrets requires more complete legal elaboration in terms of both criminal law and other branches of law, ensuring more effective implementation of statutory measures to ensure the protection of this information (Shablysta, 2012: 219).

Another state that pays considerable attention to the legal regulation of state secrets and has slightly different provisions from Ukrainian law on its protection is the United States of America (hereinafter - the United States).

In the United States, the system of restricting access to certain information is regulated by the Presidential Decree «Secret Information in the Field of National Security», according to which in the United States there are three levels of secrecy: «top secret», «secret» and «confidential». Confidential).

Moreover, information with a degree of secrecy «top secret» includes information, the unauthorized disclosure of which may cause significant harm to national security, information with a degree of secrecy «secret» - information whose unauthorized disclosure may cause significant harm to national security, and information with a degree of Confidentiality «confidential»-information whose unauthorized disclosure could harm national security (Section 1.).

Categories of information that may be classified include information:

- information on intelligence activities (including special activities), intelligence sources and methods or cryptology;

- scientific, technological or economic activities to ensure national security, which provides protection against international terrorism;

- information from foreign governments;

- on military plans, armaments or operations;

- US foreign relations or foreign activities, including confidential sources;

- vulnerabilities and capabilities of national security systems, installations, infrastructures, projects, plans or security services that provide protection against international terrorism or weapons of mass destruction; - US programs on the safety of nuclear materials and equipment (Leonov, 2009: 21).

Thus, the system of US regulations in the field of protection of classified information is too extensive, complex and cumbersome, which, however, is due to the peculiarities of the common law system, which includes American law. In US law, there is not one, as in Ukraine, but a fairly large number of criminal law, which provides for liability for disclosure of state secrets. Moreover, the criterion for the differentiation of these rules is, first of all, the subject of the crime. In other words, each category of official information corresponds to a separate rule of federal criminal law.

The authors believe that these provisions of American law are unacceptable for the domestic legal system, especially given that the sanctions of the analyzed criminal law of the United States, which provide for 
exceptionally large sentences, are almost identical («Federal Criminal Code...»).

Thus, it is possible to say that the legislation of the three studied states first of all divides the information into three blocks, and according to the degree of secrecy of information, measures and the degree of protection of information are determined.

\section{Discussion.}

Based on the analysis of the legislation of Great Britain and the USA and the Federal Republic of Germany, it should be concluded that the common law family (Great Britain and the United States) is characterized by more detailed instructions on classifying certain law enforcement information as a state secret. This circumstance is due to the precedent of the Anglo-Saxon legal system, which tends to specify the court decisions (on the protection of operational and investigative information) that can be made in the framework of certain social relations. Legislative protection of state secrets in the United States is close to the British in terms of differentiation of responsibilities depending on the category of disclosed information. The similarity also lies in the fact that the subjects of disclosure of state secrets may be persons who do not have access to such information, ie the so-called private persons. At the same time, American law distinguishes between intentional and negligent disclosure of state secrets and considers them within the framework of certain legal norms.

Thus, we believe that the features of the legislation of the studied countries identified as a result of the comparison can be taken into account during the improvement of the legislation of Ukraine in the field of protection of information with limited access, protection of state secrets.

Another promising way to protect state secrets and distinguish them from classified information will be to adopt the experience of three separate blocks of information, namely: especially classified information, the disclosure of which provides for the highest degree of punishment, classified information, responsibility for which should also be expressed and enshrined in Criminal Code of Ukraine and confidential information, for the disclosure of which to establish administrative liability.

\section{References}

1. Hbur, L. (2019). Current issues of prevention and prevention of juvenile delinquency. Law. Human. Environment: Scientific and practical journal, 10(2): 164-169 (in Ukrainian).

2. Kovalyova, S.S. \& Shpak, Yu.S. (2015). Criminal legal status of special confiscation (analysis of Articles 96-1 and 96-2 of the Criminal Code of Ukraine). Law. Human. Environment: Scientific and practical journal, 213. Available at: <http://journals.nubip.edu.ua/index.php/ Pravo/article/view/5105/5019 (in Ukrainian).

3. On state secrets: the Law of Ukraine of 21.01.1994 №. 3855-XII. Available at: https:// zakon.rada.gov.ua/laws/show/3855-12\#Text (accessed: 01.02.2021) (in Ukrainian).

4. Criminal Code of Ukraine: Law of Ukraine of January 5, 2001 № 2341-III. Available at: https://zakon.rada.gov.ua/laws/ show/2341-14\#Text (accessed: 01.02.2021) (in Ukrainian).

5. Constitution of Ukraine: Law of Ukraine of June 28, 1996 № 254k / 96-VR. Available at: https://zakon.rada.gov.ua/laws/ show/254\%D0\%BA/96-\%D0\%B2\%D1\%80 (accessed: 01.02.2021) (in Ukrainian).

6. National Security Strategy of Ukraine: approved by the Decree of the President of Ukraine dated 26.05.15 № 287. Available at: https://zakon. rada.gov.ua/laws/show/287/2015\#Text (accessed: 01.02.2021) (in Ukrainian).

7. Leyland, P. (1996). Criminal law: crime, punishment, justice (English approach). Kyiv: Fundamentals, 207 (in Ukrainian). 
8. Havronyuk, M.I. (2006). Criminal legislation of Ukraine and other states of continental Europe: comparative analysis, problems of harmonization: monograph. Kyiv: Legal Adviser, 1048 (in Ukrainian).

9. Executive Order 13526 Classified National Security Information, December 29, 2009. Available at: http://edocket.access.gpo. gov/2010/pdf/E931418.pdf (accessed: 01.02.2021) (in English).

10. Instruction sheet on the Handling of Protectively Marked Information Classified VSNURFÜR DEN DIENSTGEBRAUCH (RESTRICTED). Available at: https://www.bsi. bund.de/SharedDocs/Downloads/DE/
BSI/Sicherheitsberatung/VSMerkblattEnglisch_pdf.pdf?__blob=publicationFile (accessed: 01.02.2021) (in English).

11. Shablysta, O.O. (2012). Origins and current state of criminal law protection of state secrets. Law and society, 3: 217-220 (in Ukrainian).

12. Federal Criminal Code and Rules as amended to February 1, 1991. St. Paul., 1991: 953-1044 (in English).

13. Leonov, B.D. (2009). Peculiarities of responsibility for crimes in the field of protection of state secrets under the criminal law of some foreign states: comparative legal characteristics: textbook. manual. Kyiv: Scientific type Department of the SBU, 92 (in Ukrainian).

\section{Л.В. ГбУр (2021). ОСОБЛИВОСТІ ВІДПОВІДАЛЬНОСТІ ЗА РОЗГОЛОШЕННЯ ДЕРЖАВНОї ТАЄМНИЦІ В УКРАЇНІ ТА ЗАРУБІЖНИХ КРАЇНАХ: \\ ПОРІВНЯЛЬНО-ПРАВОВИЙ АНАЛІЗ. Право. Людина. ДовкілЛя, 12(1): 181-187. https://doi.org/10.31548/law2021.01.021.}

Анотація. У статті здійснено порівняльно-правовий аналіз відповідальності за розголошення державної таємниці в Україні та зарубіжних країнах.

Враховано те, що відомості, які становлять державну таємницю, є надзвичайно важливими для суспільства та держави. До того ж, потребують особливої та пильної охорони як з боку правоохоронних органів, державних органів так і з боку громадянського суспільства та кожного окремого індивідуума.

Підкреслено, в сучасних умовах розвитку глобальної інформаційної мережі набувають своєї актуальності проблеми вирішення доступності до інформації, а також ефективного використання державних інформаційних ресурсів, до якої входить також інформація $з$ обмеженим доступом та питання встановлення порядку для віднесення інформації ві однієї категорії до іншої. Правовий інститут державної таємниціє розвинутим в більшості країн Світу, в яких займає особливе місце та перебуває під пильною увагою з боку держави.

Булоз'ясовано, щозаконодавством трьох досліджених держав (США, Великобританія, $Ф Р Н$, перш за все йде розмежування інформації на три блоки, і відповідно до того, який є ступінь секретності інформації, визначаються міри та ступінь охорони інформації.

Зроблено висновки, що перспективним шляхом для охорони державної таємниці та розмежуванням ії з секретною інформацією буде перейняття досвіду щодо трьох окремих блоків інформації, а саме: особливо таємна інформації, за розголошення якої передбачити найвищий ступінь покарання, таємна інформація, відповідальність за яку також повинна мати вираження та закріплення у КК України та конфеденційна інформація, за розголошення якої встановити адміністративну відповідальність.

Ключові слова: інформація, державна таємничя, секретна інформація, конфеденційність, кримінальна відповідальність 